\title{
Exploring Women's Experience in Ivy League Law School Classrooms
}

\author{
Emily Kindschy ${ }^{1}$, Jeffrey Perrin ${ }^{1} \&$ Jennifer O’Neil ${ }^{1}$ \\ ${ }^{1}$ Lesley University, USA \\ Correspondence: Jeffrey Perrin, Assistant Professor of Psychology, Lesley University, USA
}

Received: August 4, 2014

Accepted: September 1, $2014 \quad$ Available online: September 23, 2014

doi:10.11114/ijsss.v2i4.482

URL: http://dx.doi.org/10.11114/ijsss.v2i4.482

\begin{abstract}
This study seeks to explore the experiences of women in the law school classroom. Participants from an Ivy League law school were placed in focus groups and asked to reflect on their law classroom experiences as it pertained to their gender. Results indicated that in an environment that adheres to typical law school pedagogy - such as the Socratic method - women experienced a multitude of challenges within the classroom. The issues reported by the focus group participants generally fell into these five main themes: (1) concern about being perceived as overly emotional or speaking from experience, (2) apprehension about discussing women's issues, (3) gender differences in participation and reinforcement, (4) gendered speech, and (5) differential treatment of female faculty members. This study demonstrates the need for an examination of pedagogical approaches to eradicate unfavorable learning environments for women in law school classrooms.
\end{abstract}

Keywords: gender, feminist pedagogy, law school classrooms

\section{Introduction}

\subsection{Women in the Legal Field}

Far from the days of women staying at home while men engage in work outside, women are now entering the workforce in equal numbers to men. According to the U.S. Bureau of Labor Statistics, (2013) 37\% of women in the United States in 2011 held college degrees compared to just $11 \%$ in 1970. As women continue to obtain advanced degrees, it would be expected that they are represented in a multitude of fields in equal numbers to men - particularly those that, historically, have been dominated by men. In particular, the idea of a woman entering law school is no longer considered shocking. Women are entering law school in equal numbers as males -- according to recent data released by the American Bar Association, of the students that were awarded J.D.s in the U.S. in 2013, 47.3\% of them were women (American Bar Association, 2013).

Though the inclusion of women in law school and in the law field is certainly promising, it is also important to note that gender equality has not necessarily been achieved in the field itself. As an example, women are still making less than men -- as of 2011, women were making $86.6 \%$ of what men were making in the field in the U.S. (ABA, 2013). Additionally, only $20 \%$ of equity partners in the U.S. are women, lateral hiring continues to favor men, and advancing women is not a universal goal among all major U.S. law firms (McCabe, 2014).

In addition to tracking wage inequities and women's representation in positions of power, it is critical to analyze the experience of women in the law school environment. If there are wage and hiring disparities, is their experience in law school contributing to these disparities? When a woman enters law school, does her original focus change after she graduates from the institution? The classroom experience plays a huge role in how women may choose to proceed after their degree has been awarded. Though law schools may be admitting women in equal numbers, this does not necessarily speak to the classroom experience that they receive while at a law institution. This study is oriented in the field of gender studies with a particular focus on feminist pedagogy. Feminist pedagogy highlights the importance of gender for analyzing experiences in formal institutions, such as law schools. In particular feminist pedagogy addresses issues of difference and inequality in the classroom through an investigation of hierarchies of power and authority (Murray, Byrne, \& Koenig-Visagie, 2013).

\subsection{Women's Experience in Law School}

In the 1990s and throughout the 2000s, there were numerous studies investigating women's experience in law school specifically addressing women's success in the classroom (French-Hudson, 2014; Purvis, 2012; Butlan, Hradsky, Jeshke, 
Meyer \& Roberts, 2008; Bashi \& Iskader, 2006; Ramachandran, 1998; Fischer, 1996; Guinier, Fine, Balin, Bartow \& Stachel, 1994; Granfield, 1992), how they feel in the classroom (Banks,1988; Granfield, 1992; Rhode, 1993; Williams, 1993; Fisher, 1996; Schleef, 2001; Krakauer \& Chen, 2003; Schwab, 2003; Bashi \& Iskader, 2006; Purvis, 2012; French-Hudson, 2014), and their career aspirations (Granfield, 1992; Krakauer \& Chen, 2003). Cumulatively, these studies paint a cohesive picture of gender inequity in law school culture during that time.

It is important to note that attributing certain traits or experiences to either females or males is not necessarily productive - in line with feminist theory, researchers should remember that these attributes should be considered as being socially constructed, in that the environment that one is put in can greatly affect one's traits. This is especially true when one looks into how women and men are socially conditioned to react and analyze situations based on their gender. As stated by Rhode (1993), "the celebration of gender difference risks not only simplifying, but also over claiming" (p. 1551). While it is critical to look at the experience of women in law school, it is even more critical to remember that the experience of one woman is directly tied to her social experiences - her race, class, and gender positionality can play a large role in how they perceive and react in a situation (Rhode, 1993).

Our study aims to add to the extensive literature on the topic of women's experiences in law school - are women's experiences different at law school institutions as their attendance rates have increased over the past 20 years? Specifically, what are women currently experiencing in law school classrooms?

\subsection{Literature Review}

According to Obiora (1996), legal pedagogy started with the establishment of the elite Harvard Law School. The Dean of Harvard Law School in 1870, Christopher Langdell, created a legal pedagogy that would frame the legal institutions that would follow. In his eyes, legal education needed to focus on law as being "homogenous, determinate, and insulated from the complexities of specific social circumstances" (Obiora, 1996, p. 357). Even further, Obiora (1996) notes:

According to the case of analysis, emotional and philosophical perspectives were not to be readily countenanced in legal discourse, and individual notions of equity and fairness were only accommodated when cloaked in the guise of universal and logically exact legal principals. (p. 357-358)

While documenting the experiences of Harvard Law Students, Granfield (1992) notes how little legal pedagogy had changed since 1870. Specifically, Granfield discusses the concept of law versus ideology - two constantly competing concepts for those enrolled in law school. He notes that these two concepts, as they can constantly be at odds with one another, serve to help law students gain their "legal consciousness" (Granfield, 1992). Essentially, as students gain knowledge of the law, they may begin to accept social conditions that they may not have prior to immersing themselves in the study of law. Though law aims to be rational and unbiased, one's ideology can play a substantial role in how the law is interpreted. In order to understand how law students gain legal consciousness, it is important to grasp how men and women typically differ in understanding and analyzing situations.

There has been much discussion about the idea of "connected knowing" and "separate knowing" when it comes to how males and females differ in understanding and critically analyzing situations. Typically, "connected knowing" is attributed to females, as they "tend to be more relational rather than adversarial, cooperative rather than competitive, and emotional and intuitive rather than strictly rational" (Schleef, 2001, p. 70). This contributes to the idea of women showcasing a 'different voice' than men (Gilligan, 1982), causing them more difficulty in being successful in a law school setting that tends to privilege "separate knowing.' Particularly, it has been stated that there is an "ethic of care" that is attributed to women - decision-making among them is normally attributed to the examination of relationships and interconnectedness (Gilligan, 1982; Krakauer \& Chen, 2003). These different voices, ways of knowing, and ethic of care versus an ethic of justice attributed to men allow us to better understand how Granfield's (1992) idea of coming to "legal consciousness" can differ in men and women.

According to Schleef (2001), "students and educators view law school as a 'trial by fire', where an atmosphere of competition and inequality is appropriate for socializing students for after law school" (p. 72). This is specifically connected to the basis of legal pedagogy - the Socratic method. As noted by Ramachadran (1998), the use of a competitive and adversarial pedagogy - like the Socratic method - alienates students and can cause lower grades, lower participation rates, and higher rates of mental illness among women and other marginalized populations. Additonally Purvis (2012) states that research indicates that law students are the unhappiest group of graduate students. It's important to note that this research also included medical students, largely viewed as the most overworked, stressed and unhappiest group of graduate students by the general public.

Numerous studies conclude that women participate less than men in the law classroom (Rhode, 1993; Guinier et al., 
1994; Ramachadran, 1998; Bashi \& Iskader, 2006; Purvis, 2012; French-Hudson, 2014). If legal pedagogy is rooted in separate ways of knowing, it is not surprising that women who are socialized to pander to a more connected way of knowing are less likely to participate in class. The competitive and adversarial nature of the Socratic method and the large size of classrooms can make it particularly difficult for those so often considered as the 'other' to consider participating (Rhode, 1993). Additionally, not only do women participate less overall, but their participation decreases as law school progresses, while rates of male participation remain stable over the course of three years (Ramachandran, 1998). This diminished participation has consequences as Bashi \& Iskander (2006) point out. This lack of participation hinders the students' ability to create relationships both with students and the professor and it also denies the student the opportunity to practice the art of debate, construct legal arguments and become more assured in the skills they are supposed to be developing in law school. This study also points out that faculty simply give more attention to students who speak up quickly and that this is "unequivocally behavior that is displayed by men"(Bashi \& Iskander, 2006, p. 9).

Additionally it's important to look at the possible reasons why women participate less in law school classrooms. French-Hudson (2004) points out that men will often raise their hands even if they aren't prepared while women will take time to think the question through before attempting to participate. By this time, the professor has likely called on someone to answer the question. Additionally, she found that women are more likely to "raise their hands when the comment is substantive and of high quality" (French-Hendson, 2014, p.84). Butlan et. al (2008) noted similar results with women only participating if they were sure they were adding something to the conversation. Faculty management of the classroom plays a role in this as well, meaning the more aggressive the professor is the more likely the aggressive student is to be successful in their classroom.

Two studies also used the term "gunner" when taking about classroom participation (Butlan et. al 2008; French-Henderson, 2014). A gunner is a student who talks too much and takes up too much time in class. Both studies notes that women take more harassment from fellow students if they are known as a gunner and it is more the norm for men to fill this role with little comment from classmates. French-Hudson (2014) pointed out that women are often socially and culturally pressured not to talk too much and a student in the Butlan et. al study started to believe that she was actually an inferior law student because she was a student who "learned by listening" rather than by speaking and taking the role of a gunner (2008, p. 140).

In addition to low class participation, another area that is examined thoroughly in previous studies is how students connect with professors outside of the classroom. In many law schools this connection can be just as important as the work done inside the classroom. As one might suspect men have much less trouble connecting with professors in these situations (Butlan et. al, 2008; Purvis, 2012; French-Hudson, 2014). Much of the research shows the same result. Female law students will seek out law professors outside the classroom when they have concrete questions and are prepared to ask and receive answers. Male students however will visit professors to talk about their day, share information about themselves and in some instances try to gain favor with the professor. Put simply male law students demand attention and the professors reward their demands.

Bashi \& Iskander's (2006) found that male faculty is less likely to follow up, press, challenge or argue with a female student. They contend that male professors are more willing to push a male student because they have fewer concerns about offending that student. They go on to posit that this treatment could also affect the level of confidence displayed by female students. When women are not integrated into the classroom experience they become less visible in the law school experience.

In Schleef's (2001) study, one of the biggest criticisms to the structure of law school is the absence of a voice that considers relationships and compassion. As noted in her study, students were consistently taught to detach themselves emotionally from a case and told that this skill would serve them later in the field. Both Schleef (2001) and Guinier et al. (1994) report that by the end of their law school experience, women felt that their education had fundamentally changed them - not necessarily in a positive way. Some noted that they felt they were no longer compassionate or became more "conservative" once their time in law school had been completed (Granfield, 1992; Schleef, 2001; Guinier et al., 1994).

In several research findings (Granfield, 1992; Schleef, 2001), it was first-year women who reported the most discomfort in the classroom. Women who enter into law school with social justice interests or a feminist pedagogy typically report feelings of alienation and general displeasure with the experience of law school. Interestingly, in both studies done at two Ivy League schools, (Harvard Law School and University of Pennsylvania) researchers concluded that students with a more radical view of women's rights either did not do as well as their peers or eventually began to view the staff as particularly sensitive to issues of gender by their second and third years (Granfield, 1992; Guinier, et al, 1994).

According to Granfield (1992), while women at Harvard Law School agreed that they would like to see more female representation on the faculty and other positions in the legal world, they were divided by ideologies. As stated above, women who entered law school to pursue social justice were more likely to view the law school experience as 
dehumanizing and oppressive (Granfield, 1992). Additionally, Granfield found that all students entering Harvard Law School with interests other than working in a corporate setting often changed their career choices upon graduation; many stating that upon finishing their legal education, their cynicism led them to believe that the law cannot be helpful in terms of public interest jobs.

Interestingly, when looking at this topic in an international context, women seem to be experiencing similar injustices in law school classrooms around the world. In particular, Margaret Thornton's groundbreaking book Dissonance and Distrust: Women in the Legal Profession (1996) shed light upon the "otherness" that women in Australian law schools felt. This "otherness" as described by Thornton falls in line with literature focused in the United States, particularly in terms of experiencing blatant sexism (sexist jokes, comments about appearance, etc.) and receiving fewer academic and professional opportunities, and assumptions being made about their capacity for legal reasoning due to their gender (Thornton, 1996; Liu, 2013; Mundy, 2013). Thornton's work goes even further, discussing the gendered experiences and issues that arise once female law students enter the law profession (Thornton, 1996).

Chinese women in legal education as researched by Xianonan Liu also experience similar issues. Liu's (2013) comprehensive analysis of women in the legal profession in China discusses issues of blatant male preference in enrollment as an "unwritten rule" (Liu, 2013, p. 1325), female faculty holding the lowest ranked positions, lower expectations for female students, and societal beliefs that women are not suitable to study law despite outperforming men, grade-wise (Liu, 2013). Due to the nature of gender dichotomies as a central belief in China, the push for gender equality and abolishing gender essentialism as it pertains to women law students continues to be a contentious topic (Liu, 2013).

The aim of this study is to investigate women's experience in an Ivy League Law School classroom. Specifically, this research was guided by questions related to women's participation in class discussions and perceptions of student-student interactions and faculty-student interactions. We hypothesized that although there is a multitude of research indicating that women have different and sometimes negative experiences in law school that the nature of their experiences will not have changed despite growing knowledge of their gendered experiences and issues.

\subsection{Purpose of this Study}

The aim of this study is to investigate women's experience in Ivy League Law School classrooms. Specifically, this research was guided by questions related to women's participation in class discussions and perceptions of student-student interactions and faculty-student interactions. We hypothesized that although the number of women attending law school has increased, women's experience in the classroom would not differ from reports in the 1990s and 2000s due to the valued ways of knowing in legal pedagogy.

\section{Method}

The use of focus groups was especially appropriate for our research for several reasons. First, focus groups allowed us to understand the consensus and diversity of responses among focus group participants. Focus groups are specifically designed to allow research participants to discuss and agree or disagree about attitudes, interactions, and experiences (Kitzinger, 1995). The group effect of interacting with others, offers a tremendous opportunity to understand complicated behaviors, cognitions, emotional responses, and motivations (Morgan, 1996). Second, focus groups encourage participants to identify, describe, and analyze key issues and experiences (Agar \& MacDonald, 1995; Kitzinger, 1995). Finally, focus group practices are aligned with feminist pedagogy and group processes focusing on the personal as a way of knowing and giving particular weight to feeling, experience, and thought (Bowker \& Dunkin, 1992).

\subsection{Sample}

The sample from this study resulted from purposive (homogenous) and snowball sampling of women currently enrolled at an Ivy League Law School. We posted recruitment flyers around campus with criteria requiring participants to be at least 18 years old, identify as female, and currently be enrolled in an Ivy League Law School. Potential participants were instructed to contact a member of the research team for instructions on the focus group time and location. Participants in the first three focus groups were asked to 'spread the word' to other female law students about the study.

\subsection{Participants}

We conducted four small focus groups (14 total participants) of female law students. Participants ranged in age from 23-31. Nine identified as Caucasian, three identified as African American, one identified as Asian American and one identified as "mixed". 


\subsection{Procedure}

Two female members of the research team conducted all of the focus groups on the campus of the research sponsoring institution. In order to develop rapport and create as non-threatening environment as possible, male members of the research team did not conduct any of the interviews. In order to create consistency between the focus groups the same female researchers acted as moderator and assistant moderator. The moderator asked all of the questions. The assistant moderator took notes during the discussion and made sure the moderator did not miss any participants trying to add comments to the discussion.

Before each focus group all participants were asked to complete a short demographics questionnaire. Next, the moderators explained the protocol for the session and then each participant signed an informed consent. The moderator conducted focus group sessions with open-ended questions and frequently followed up with clarifying probes. Questions concentrated on women's experience in law school classrooms, specifically asking them to focus on class participation dynamics, interactions with classmates and faculty members, and discussion topics in the classroom. At the end of the semi-structured list of questions, participants were asked if there were any other questions related to gender, pedagogy, and law school classroom dynamics that they would like to discuss. Each focus group lasted approximately 90 minutes. Following each session participants were thanked for their time and compensated with \$20. In addition, each participant received a debriefing form with the names and contact information of the principal investigator and the sponsoring institutions' chair of the institutional review board. We provided pizza during the focus groups sessions. All focus groups were audio taped with the permission of the participants. We held focus groups until we reached a saturation point.

\subsection{Data Analysis}

Audio recordings were transcribed verbatim and all data that could identify the participants were removed to preserve anonymity. We used an inductive thematic approach to examine data for recurring issues that were then grouped together by means of a coding system. Next, we grouped similar codes together into more general main categories. Finally, these categories were organized into five main themes. In order to ensure reliability of data interpretations, two researchers independently carried out the analyses. Any disagreements were discussed with a third member of the research team until all researchers were in agreement.

\section{Results}

The issues reported by the focus group participants generally fell into these five main themes: (1) concern about being perceived as overly emotional or speaking from experience, (2) apprehension about discussing women's issues, (3) gender differences in participation and reinforcement, (4) gendered speech, and (5) differential treatment of female faculty members. In the text below we will summarize each one of these themes.

\subsection{Speaking from Experience and Emotional Arguments}

Many of the participants discussed how speaking from experience and storytelling was perceived by others in the classroom. Specifically, participants mentioned that personal experience is often not valued in the classroom. For example, Participant 2.2 (Focus Group \#2, Participant \#2) stated, "There was a girl in our criminology class who went into great detail about stories and experiences she had had relating to the crime. I can't really speak to the professor, but I know it really annoyed a lot of students. " Furthermore, Participant 3.1 explains why personal experiences are often not endorsed in the classroom.

"I think because class participation doesn't count for the grade when people share their own personal experiences other students feel annoyed because you aren't saying anything that I can write in my exam. What you are saying right now is currently not something that I currently want to hear. We can have this discussion outside of class, but do not take my class time to distract from my end goal, which is to get a good grade. I think that it is more about law school being only based an exam, instead of also considering class participation. It makes it even harder to make arguments about your personal experience because everyone is like 'well that is not going to be relevant. I can't use that as a support for what I am trying to argue.",

Participant 2.1 also noted the importance of "blocking out all the things that are just noise and just really focusing on what the specific legal question is because that's all that really matters... You want to analyze it and forget you are a human."

Furthermore, participants observed a relationship between the likelihood of sharing personal stories and gender. As an illustration of this relationship, Participant 2.1 claimed, "I think that women tend to bring in personal stories more. I mean I have definitely heard them from men, so it's not like only women, but I think they are more likely to." Participant 2.2 noted a reticence to present emotional arguments: 
"I also think that when I'm in class I feel like I have to be more on guard about making an emotional argument because I don't want people to be like 'oh she's a girl'. I think it all comes back to criminology because that's the class that has the most relationships for people. But you want to be careful in terms of the arguments you're making on justice or being fair because you don't want others to think 'she's not strong she's just like thinking about the children.",

3.2 Apprehension about Discussing Women's Issues

Female participants indicated a noticeable reluctance of female classmates to discuss women's issues in the classroom.

"In larger lecture classes there are certain topics which you would think women would talk more about, but, they don't, like abortion or rape. Those classes no women talk at all. I think that is really interesting that topics that you associate with women's rights and issues women were particularly silent" (Participant 1.4).

Participant 1.5 provided an example from her constitutional law class:

"When we were talking about Roe v. Wade I'm pretty sure that during the entire class discussion there was only one female who spoke up and there were about 10 students who talked. One of the comments was by a man whose wife had just gotten a sonogram for their child and he raised his hand and said I don't understand how anyone could have an abortion. I was really traumatized by this and I'm a foreigner and this is not how things are in my country, so it was really terrifying. These kinds of comments I don't think would come from women because it is really exposing yourself, whereas men might feel a bit more confident in larger group settings."

Participant 2.1 offered an example from her torts class, "we did a little bit of feminist legal theory in our Torts class. I feel like in the rape discussion it was still more men than women talking, which was shocking."

In an effort to explain this phenomenon, Participant 4.2 references the relationship between the intensity of the topic and apprehension to comment in class, "Regardless of women's general willingness to participate, I think the conversation get most heavy when its women's issues and that is when they probably feel a little bit more uneasy about participating." Although Participant 3.4 has been a contributor to gender-related discussions in the classroom, she considers speaking less about gender issues in the future due to a fear of representing all women:

"A classmate came up to me and I think this was after people had started talking about gender issues at law school and how being a woman affects your life here. They said 'that's not true you talk all the time in class and you're a woman'. And it was kind of like, hmm yes, but not necessarily. It was interesting because their argument was that I talked in class and I seemed comfortable with it and I was a woman, so therefore there is no possible way a woman could have a hard time talking in class. It was concerning to me because it was like wait you think I can speak for every single one of the women in our class, that's a problem. It made me consider speaking less, not necessarily because of that guy, but if there are people who think I am speaking for all the women, maybe I should keep quiet so that maybe some other woman can speak, so they can see that I am not the only one who has an opinion in this class."

\subsection{Gender Differences in Participation and Reinforcement}

Focus group participants reported an implicit and explicit endorsement of made up answers in the classroom. Participant 1.6 highlights this process:

"The worst thing was just to not saying anything and to just pass or just say I don't know. Whereas if you can at least say something even if it was totally off base you were rewarded a lot more. Even if you were bullshitting through the answer, they would be like oh okay. A good professor would take that answer and make it the right answer. You are definitely rewarded for bullshitting even if you don't know the answer."

Participant 1.4 discusses the relationship between student responses to questions and professors' responses, "I think the students who receive the most positive feedback, in terms of follow up questions are more of the people who initially bullshit their response. They are the ones who kind of stimulate the professors' conversations." This phenomenon contributes to a reluctance to participate. Participant 1.4 adds, "I realize what they're saying is BS and I don't want to participate for that reason."

Some interviewees noted a difference in the frequency of participation between males and females and differences in reinforcement. For example, Participant 2.1 noted "we definitely have a few women who speak regularly, but of the people who are really vocal in class the majority of them are men. I think they are encouraged more and followed up more and just in general there is a huge difference between men and women in the classroom." When referencing a specific example in class, Participant 2.1 added, "The strangest thing about that is probably the one or two who were contributing and probably who made the smartest comments in the class were not men. And they didn't get that 
treatment." While discussing how males respond to professors' questions, Participant 1.6 shared this anecdote from class, "I did notice a lot that guys often would be making a joke or kind of put off responding, or say something and make everyone laugh. Whereas, if it was a girl they would be frantically looking for the case or the answer."

Participant 2.1 noted:

"Sometimes you raise your hand and you say something and that's it and you move on. Then sometimes your professor will latch onto it and come back at you with something, maybe a hypothetical or follow up question and it will be more of a discussion. I think that happens more with men. I don't know why. It depends on what they are asking or just because of gender bias and things like that. Also, I have the same sexist professor, who will come back with sexist things. You know coming back with a hypothetical about you know your husband who works and you who don't. Things like that, that are not necessary to the situation or to the question. That automatically put that woman in a different place when answering the question."

Participant 3.3 remarked:

"I feel like women kind of they check themselves before they speak in a way that men don't-is this going to contribute to everyone's learning experience or did I make sure that I really understand everything so I don't sound stupid? Men don't think those thoughts. They just talk."

Finally, Participant 3.1 adds, "Women tend to think a lot more before they talk, it tends to be the men who more often than not that say something that is just absolutely like you did not even think about that before you spoke. Women don't tend to do that."

In another part of the focus group, participants specifically referenced examples of female faculty members reinforcing male comments in class. For example, Participant 2.2 discussed an example of a female faculty member emphasizing male participation:

"My scary professor from last semester used to like it if someone came up with an idea and she would call it 'Joe's idea' or whatever. She would refer back to those ideas and ask 'do you agree with Joe's hypothesis' and the only people she raised to the level of getting their own named hypothesis were men."

Participant 2.1 added:

"I agree. I think about it a lot. I mean the moment you walk into the building it's lined with pictures of tenured professors, which are $80 \%$ men at least. Mostly white men, so from the beginning we're primed that's whose in charge. I agree that we've had a few female professors, but when you start doing the numbers there aren't that many of them, but even the female professors tend to give more encouragement and call on men more. Men definitely talk more and if you start keeping track, which I knew a few people in our class have done off and on, there's a pretty big imbalance.

In addition to reinforcement from faculty members, Participant 2.1 identified the Socratic method as a contributor to participation disparities between males and females:

"I think that confidence issues that have been bred in us come out in the Socratic method. I think women get automatically more flustered when they get called on because of those confidence things whereas guys will come out faster with an answer, even though it might be completely wrong or stupid. I think the women are more likely to freeze than answer stupidly. I think that the stupid answer is more acceptable to the professor because they will find a way to spin it and come up with something rather than freezing and being awkward and then they don't know what to do with that."

\subsection{Gendered Speech/Demeaning Speech}

Female participants in the focus groups cited several instances in which they were spoken to differently because they were women. For example, Participant 1.5 shared an anecdote from her negotiation workshop:

"In the last negotiation there was a case about divorce and we were pretending to be the people getting divorced. On my team there was me and another female and we were negotiating with a team of males, just by chance. We were representing the man and they were representing the woman, again by chance. At some point, I said something to represent my client, something like 'he needs money for his new apartment because his ex-wife is living in the house.' Someone who was in the previous year was in my section he said, 'oh you can't be serious. You can't seriously believe that.' I just thought 'what?' There is no way he would have said that to a male attorney. The only reason he told me that what I was saying was not serious was because I was female. It was so clear in that moment that he was treating me differently."

In addition to instances of being spoken to differently by male classmates, other participants shared stories of being spoken to in gendered ways by faculty members. 
"I have a professor this semester who is very sexist and that's the first time I've kind of really thought about my role as a woman in law school. One of my co-students, went to him for office hours and said that she didn't understand the material and he was like 'well you just need to be more confident' and kind of spoke to her in very gendered ways" (Participant 4.2).

Participant 4.3 highlighted a discrepancy in the way males and females are evaluated in mock oral arguments:

"So as a $1 L$ (first year law student) we participate in the Ames mini court competition. It is not full on Ames, but everyone has to do it for LRW. We first had to do a mock oral argument with student advisors on campus. When I was in high school I did debate competitively and then I did it in college too. So this is not something I am unaccustomed to hearing, but I had my advisors tell me that I was too feisty and it almost came off as bitchy. It was very frustrating because I know if I had been a man standing up there they would definitely not have used the word bitchy and they definitely not called him feisty and they probably would have called aggressive and assertive and they probably would have applauded it. I think because I am female, I am not allowed to be as feisty as the men."

Participant 1.6 discussed a strange incident of being interrupted by an instructor:

I'm trying to think of an example especially in trial ad. There's this one judge, so trial ad they bring in all the instructors who are current practitioners from all over the country. They come and basically rip you apart for a week and you feel terrible- like the worst you ever felt in law school because you do nothing right. There is one judge who came in and it was the first day I was there and trial advocacy is 7 hours long it's like 2-9 everyday. Sometimes you have to leave and come back for class. The first day he was there I had class and I was late from a class and then I immediately was told I was going. I had to get up and start doing my direct examination and I was like flustered because I wasn't ready and I think, I don't remember, but I couldn't think of what to ask next. I was pausing a lot and saying 'um'. Then he said, 'okay breathe'. He interrupted me and said, 'stop'. That had never happened and this was the second week of trial ad. I said okay and he said now 'breathe with me' while I was standing up in front of everybody. I didn't even want to do it again all I wanted to do was get this moment over with and move on. Then he said, 'okay you feel better now?'I was like 'yes, but no, no, no.' He said okay go calm down and I was like 'okay'. Then I rushed through it and that ruined the day for me and the confidence of doing any of it correctly. I don't know if he would have done that to a guy. I don't know if he would have interrupted me and stopped me and then make me breath with him to calm me down. That was very weird to me.

Participant 4.4 highlighted an instance in which a male attorney told a classmate, "I know you have hair, but you need to not play with your hair." In other instances, participants cited examples of non-verbal differential treatment. For example, Participant 2.1 shared the following anecdote:

"A female student was organizing something that another male student could help her with for class. She asked him to help her and so they went to speak to this professor in his office to tell him what they'd done. She was clearly the main person who talked about this and at the end of it they stood up and she was closer, yet, he didn't shake her hand and went to the man and shook his hand and said 'good job'. Then they left. It wasn't intentional 'oh, I'm not going shake your hand', but it was like a happenstance situation and she was really upset. She was crying and talked to him. It was her thing and he was sort of there as well, yet, he was getting all the credit and getting the encouragement."

In addition, Participant 1.5 added "yesterday in class, I asked a question and then the professor very intently answered while looking at a man for 2 minutes- just answering and talking to a man."

In other instances participants spoke about faculty members introducing inappropriate details in there case examples. For example, Participant 2.1 shares a story about her 'sexist professor':

"We can just tell you stories about our sexist professor. I don't know like the first or second week, he is a very prominent man and very old and knows a lot of people in very high up places, and so he tells us stories about judges. When he talks about female judges he talks about how they slept around a lot. And, he's like 'oh you can go a read about it.' When he talks about the men, he's says they are a good judge and they did this and that. He did tell us she was a good judge, but he also said she used to be a Playboy bunny. And other very unnecessary things."

Participant 2.2 added another instance of that faculty member presenting a case example with demeaning commentary:

"Another thing he talked about was a case where people in a relationship were breaking up and it was a contracts list, so we focused on what they were splitting in terms of the marriage contract. He spoke very much 
that the woman testimony couldn't be trusted and she was probably emotional. He more than implied he basically said that she was giving sex and so she was getting supported and that was like the quid pro quo of the relationship and that was like what a relationship is. And, he said that same thing in regards to other cases in which coupes were breaking up or like a mistress case. He harped on that a lot and people went to the dean and he half-heartedly apologized, but I don't think his perception has changed at all."

\subsection{Differential Treatment of Female Faculty}

Focus group participants also highlighted what they perceived as differential treatment of female faculty members. Participant 1.6 discussed student's response to a visiting female faculty member:

"In my 1st year, I only had one female professor the whole year and she was a visiting professor. She was treated so different then every other professor that I had. A group of vocal female that were very abrasive actually went to the dean about this professor within the first two weeks of class. Everybody just spoke so badly about her the whole year and complained about her the whole semester. All the complaints were exactly the same as my male professor had done fall semester. I felt like, yes, I was frustrated as well, but everything she was doing that I disagreed with was exactly what he had done. But everyone respected him because he was a more prominent professor in the law school and I thought it was because he was a man and I thought that multiple times. It was very apparent to me she was the only one of my professors who didn't get immediate respect when we walked into the classroom the first day."

Similarly, Participant 3.2 discussed a double standard for male and female faculty members:

"I found that students, in my opinion, spoke more negatively about our female professors. We had one each semester during our first year and in our section I heard more negative comments coming about the females professors than about any of our other professors probably combined. Even thought there were only 2 or 3 of our professors who were really great professors. There were only 2 or 3 of them. You don't even expect them to be like amazing teachers. You expect them to be like amazing academics that have written amazing papers. That is it. But when a woman did it, they were extremely critical of it and that definitely affected me and how I spoke of my professors and what I thought of them. I was a lot more careful when I talked about my female professors than I was about the male professors because I knew that I didn't want to play into any biases that people already had. To this day, I have taken another class with one of the female professors and I am really careful about how I speak about the class and the way I speak about the professor because I know my classmates have a negative perception or a more negative perception of this person. Not just her teaching style, but her intelligence and her knowledge of the law has come into question the way that this professor gets off track. Other professors get off track quite a bit and their knowledge of the law was never fully questioned in the way that this professor has."

\section{Discussion}

Our findings support past literature regarding women's fear of speaking from experience in the classroom due to the likelihood of being deemed too emotional (Rhode, 1993; Guinier et al., 1994; Ramachadran, 1998). Referring back to Laws (1975) quote about the institution of tokenism, it would seem that as women enter a field that has typically been male-dominated, they have been taught to self-silence as to not interrupt the system that is in place in order to be successful and looked upon highly by peers and faculty.

Female participants also reported a reticence to discuss women's issues in the classroom. Though there is little research regarding the specifics of hesitance to discuss women's issues in a classroom setting, there is a multitude of research that discusses women's reticence to call out sexist behaviors for fear of experiencing disrespect or being labeled too emotional by their peers or people in higher authority (Ayres, Friedman, \& Leaper, 2009; Dodd, Giuliano, Boutell, \& Moran, 2001). The method by which our participants chose to cope with the discussion of issues that pertained to them was to enact self-silencing, which has been heavily researched in regards to how it affects women (Hurst \& Beesley, 2013; Swim, Eyssell, Murdoch, \& Ferguson, 2010).

Both Ayres et al. (2009) and Dodd et al. (2001) concluded that the likelihood that a woman would confront a perpetrator of sexist behavior is connected to the perceived social costs of the confrontation. For our participants, confronting sexism in the classroom - whether it is blatant sexism or the discussion of women's issues in a disrespectful manner by men in the classroom - could not only affect their social lives, but also their grades and success in law school. Interestingly, Dodd et al. (2001) also found that women who confronted sexist remarks were less liked by male participants in the study. This likely contributes to the hesitance that women exhibit when wanting to confront issues regarding women's rights in the classroom.

Additionally, the idea of speaking on behalf of all women when women's issues were brought up was discussed by our participants. It would seem that though women are in law school in equal numbers, there is still a sense of tokenism that 
comes with being a woman in the law school classroom. As explained by Laws (1975):

The Token does not become assimilated into the dominant group but is destined for permanent marginality. The Token is a member of an underrepresented group, who is operating on the turf of the dominant group, under license from it. The institution of tokenism has advantages for both for the dominant group and for the individual who is chosen to serve as Token. These advantages obtain, however, only when the defining constraints are respected: the flow of outsiders into the dominant group must be restricted numerically, and they much not change the system they enter. Tokenism must therefore be regulated. The mechanism for the regulation of tokenism is a role partnership composed of Token and Sponsor, which together embody and enforce the limitations on participation by members of the underrepresented group in the dominant group. (p. 51-52)

Building on past research about tokenism, McDonald, Toussaint, and Schweiger (2004) found that status plays a large role in female token's experiences in male-dominated spaces. According to McDonald et al. (2004) as women went up in status, there were less negative consequences in tokenism situations. This links to previous research done by Yoder, J.D., Schleicher, T.S., \& McDonald, T.W. (1998) whereas token women were given more status - and having that status organizationally legitimized and recognized - they were less likely to report negative consequences of their own tokenism as females.

McDonald, Toussaint, and Schweiger (2004) also recognize that women's socially constructed status is lower than men, which leads to gender disparities in male-dominated fields. In terms of our participants, they longed for more female representation in high status positions in law, likely to decrease their token status and increased willingness to discuss issues that pertain to women.

Focus group participants also reported a trend of males participating in classes more than females. Research examining male and faculty participation rates in undergraduate classroom has produced similar conclusions (Banks, 1988; Crawford \& MacLeod, 1990; Wingate, 1984; Fassinger, 1995) across different size classes, courses in different disciplines, and regardless of the percentage of male and females students in the class (Wright \& Kane, 1991; Karp \& Yoels, 1976; O'Keefe \& Fampel, 1987). Interestingly, in courses taught by women, females talk proportionately more than in courses taught by men (Karp \& Yoels, 1976).

Crawford and MacLeod (1990) found that women are significantly more likely than men to attribute their lack of participation to poorly formulated ideas, fear of appearing unintelligent to their peers, and ignorance about the discussion topic. On the other hand, males are more likely to be silent because they are unprepared or fear negative effects on their grade. Finally, amongst graduate students, Kramarae and Treichler (1990) found that males remain silent when unfamiliar with a topic, while females' silence may be in response to classroom processes, such as competition or pressure. Fassinger (1995) found that females are more likely to respond to the emotional climate of the classroom and that their participation is related to confidence.

Female participants also reported that female and male faculty members generally reinforce males' comments more frequently. These findings support previous conclusions by researchers investigating the role of gender in the undergraduate classroom. Hall and Sandler (1982) conclude that women are disadvantaged in the college classroom due to differential treatment by instructors, such as recalling male students names more frequently, ignoring and interrupting females students, calling on male students more often than female students, asking less difficult questions of women, giving more feedback to men than women, and making more eye contact with males. Similarly, Constantinople (1988) found that professors tend to expand upon male students' comments more frequently.

Auster and MacRone (1994) report that because our educational system is hierarchical, competitive, and individualistic it favors more masculine forms of communication. Because feminine forms of discussion focus on establishing connection and forging consensus, females may be less likely to participate. We believe this particularly germane in law school settings that foster individualism through the Socratic method.

Female participants reported instances of gendered speech, or sexist language in the classroom by professors. Research examining differences between benevolent sexism and hostile sexism in different areas, such as the workforce, hiring processes, and different classroom subjects have discussed the negative outcomes of such behavior (Dumont, Sarlet, \& Dardenne, 2010; Good \& Rudman, 2010; Logel, Walton, Spencer, Iserman, \& von Hippel, 2009; Swim, Mallett, \& Stangor, 2004). Dumont, Sarlet, and Dardenne (2010) found that in instances of benevolent sexism -that is, remarks that seem positive towards women but perpetuate a sense of ineptitude attached to women in comparison to men - women were more likely to experience impaired cognitive performance and lower confidence in their work related competencies. Logel et al. (2009) concluded that women in typically male domains (in their research, the math and engineering fields) who experienced sexist remarks from the men were more likely to experience social identity threat and stereotype threat. That is, women in these environments who encountered sexist men, as is congruent with past 
research, were more likely to underperform in their field due to feelings of incompetency.

In the work of both Swim, Mallett, and Stangor (2004) and Good and Rudman (2010), the issue of inability to recognize subtle sexism - or benevolent sexism - proved to disadvantage women, which we believe to be an issue for law school women in the classroom. Swim,et al. (2004) found that those who endorsed modern sexist beliefs were less likely to have the ability to identify sexist behaviors. Good and Rudman (2010), when studying differences between hostile sexism and benevolent sexism in the interviewing process found that observers who evaluate an interviewer who exhibited subtle sexist behaviors favorably were more likely to deem female applicants as inept for the management position they were applying for. This is particularly problematic for women in institutions with higher percentages of men in power in that if the authority figure that exhibits subtle sexist behaviors is well liked, women will be labeled as more incompetent as a result.

Focus group participants perceived a differential treatment of female law school faculty. These statements are aligned with research highlighting gender discrimination against women faculty in academic medicine (Carr, Ash, Friedman, Szalacha, Barnett \& Moskowitz, 2000; Hostler \& Gressard, 1993); business schools (Whitworth, Price, \& Randall, 2002), and undergraduate education (Centra \& Gaubatz, 2000). Students generally rate male instructors higher on knowledge of subject matter and overall competence (Basow, 1995; Carli, 1999) suggesting that female instructors are held to a higher standard of competence and must demonstrate a higher skill level than male faculty in order to be considered competent (Sandler \& Hall, 1993; Foschi, r). Research on undergraduate evaluations of faculty demonstrates that male instructors are expected to be intelligent, rational, and highly competent (Bachen, McLoughlin, \& Garcia, 1999; Bauer \& Baltes, 2002).

Bennett (1982) found that a direct gender bias is not always found in formal student evaluations of instructors. However, female faculty members are susceptible to culturally conditioned gender stereotypes that suggest that students are less tolerant of female instructors. According to Bennett (1982) students demand a higher standard of formal preparation and organization from female faculty members. Furthermore, when students do not perceive women to be experienced and professional in their teaching style they are less likely to be accepted as providing authoritative and fair instruction. Bachen et al. (1999) conclude that the standard for female faculty is connected to objectivity, authoritarian, and competency, but is also linked to the deferential qualities of femininity such as warmth and support (Martin, 1984). Kierstaad, D'Agostino and Dill (1988) found that warmth and interpersonal contact are particularly important for female faculty members. In fact, warmth, charisma, empathy, and accessibility are more positively linked to positive evaluations for females than males (Bachen et. al, 1999; Bennett, 1982). Furthermore, when female instructors are a visible minority they are more likely to be evaluated in line with the characteristics of the gender stereotype. This is particularly relevant in our research since focus group participants reported far fewer female faculty members than males.

Negative formal or informal evaluations from students could be particularly harmful for women faculty. Kogan, Schoenfeld-Tacher, and Hellyer (2010) found that male and female faculty members react differently to evaluations. Since women's self-esteem is more closely linked to relationships with others, negative evaluations will provide a more direct challenge to women's self-esteem. Contrastingly, men's self-esteem is more closely linked to achievement, therefore rejection in the form of negative evaluations may not threaten their self-esteem as directly, resulting in a coping advantage in environments of harsh criticism (Kling, Hyde, Showers, \& Buswell, 1999). If female law school faculty share the opinion that they are treated unfairly and held to a different standard than male faculty members, this may have a great impact on efforts to balance the gender ratio amongst law school faculty. Environments with high reports of gender discrimination are extremely damaging affecting self-confidence, self-esteem, collegiality, and frequently contributing to reports of isolation amongst women faculty potentially leading to less women entering professional academic environments (Carr et. al, 2003). Our results highlight the need for future research on female faculty member's first-hand account of their experiences in legal academia.

We believe that participants concern about being perceived as overly emotional or speaking from experience apprehension about discussing women's issues; perceived gender differences in participation and reinforcement; gendered speech; and differential treatment of female faculty members can be explained by relational feminist theory. Building upon Gilligan's (1982) work in moral psychology, relational feminist thought focuses on differences between men and women in moral reasoning and fundamental orientations toward the world (Minow, 1990). Relational feminist thought concentrates on the trivialization of feminine traits such as nurturing, empathy, and caring for others, and the over emphasis of masculine traits such as autonomy, aggression, and lack of emotion. This study demonstrates great gender inequalities, as emphasized by relational feminist theory, are still occurring in the law school classroom, regardless of the overall increase of female law students.

\section{Conclusion}

Taking into account the fact that women are entering law school at equal rates as men this study examined the experiences of women in the classroom at an elite law school. Participants in our study referenced gendered speech and 
gender different participation in terms of how they were both spoken to in the classroom and how they were supposed to speak in the classroom. Many participants outlined a reticence to speak about women's issues so that they would not seem to "emotional" which would seem to be viewed as a weakness according to law school pedagogy (Obiora, 1996). Research participants not only outlined their experience in the classroom but also discussed the experience of female faculty members in law schools. Identifying these biases highlights the need for investigating pedagogical interventions to eliminate unfair treatment of female law students and faculty members in law school environments. This study adds to the ever-growing literature regarding the failures of legal pedagogy as they relate to women's experiences, in the law school classroom. There is clearly a critical need for those who hold the authority and power to consider how legal education and culture is cultivated in the classroom.

\section{References}

Agar, M., \& MacDonald, J. (1995). Focus groups and ethnography. Human organization, 54, 78-86.

American Bar Association. (2013). A current glance at women in the law. Retrieved from http://www.americanbar.org/content/dam/aba/marketing/women/current_glance_statistics_feb2013.authcheckdam. pdf

Auster, C. J., \& MacRone, M. (1994). The classroom as a negotiated social setting: An empirical study of the effects of faculty members' behavior on students' participation. Teaching Sociology, 22, 289-300. http://dx.doi.org/10.2307/1318921

Ayres, M., Friedman, C., \& Leaper, C. (2009). Individual and situational factors related to young women's likelihood of confronting sexism in their everyday Lives. Sex Roles, 61(7/8), 449-460. http://dx.doi.org/10.1007/s11199-009-9635-3

Bachen, C. M., McLoughlin, M. M., \& Garcia, S. S. (1999). Assessing the role of gender in college students' evaluations of faculty. Communication Education, 48(3), 193-210. http://dx.doi.org/10.1080/03634529909379169

Banks, T. L. (1988). Gender bias in the classroom. Journal of Legal Education, 38, 137-146.

Basow, S. A. (1995). Student evaluations of college professors: When gender matters. Journal of Educational Psychology, 87(4), 656-665. http://dx.doi.org/10.1037/0022-0663.87.4.656

Bauer, C.C. \& Baltes, B.B. (2002). Reducing the effects of gender stereotypes on performance evaluations. Sex Roles, 47(9-10), 465-476. http://dx.doi.org/10.1023/A:1021652527696

Bennett, S. K. (1982). Student perceptions of and expectations for male and female instructors: Evidence relating to the question of gender bias in teaching evaluation. Journal of Educational Psychology, 74(2), 170-179. http://dx.doi.org/10.1037/0022-0663.74.2.170

Bashi, S. \& Iskander, M. (2006). Why legal education is failing women. Yale Journal of Law and Feminism, 18(2), $389-430$.

Batlan, F., Hradsky, K., Jeschke, K., Meyer, M., \& Roberts, J. (2009). Not our mother's law school: A third-wave feminist study of women's experiences in law school. The University of Baltimore Law Forum, Spring: 124-151.

Carli, L.L. (1999). Gender, interpersonal power, and social influence. Journal of Social Issues, 55(1), 81-90. http://dx.doi.org/10.1111/0022-4537.00106

Carr P.L, Ash, A, Friedman R.H., Szalacha L,, Barnett ,R.C., Moskowitz, M.A. (2000). Faculty perceptions of gender discrimination and sexual harassment in academic medicine. Ann Intern Med, 132, 889-896. http://dx.doi.org/10.7326/0003-4819-132-11-200006060-00007

Carr, P. L., Szalacha, L., Barnett, R., Caswell, C., \& Inui, T. (2003). A 'ton of feathers': gender discrimination in academic medical careers and how to manage it. Journal Of Women's Health, 12(10), 1009-1018. http://dx.doi.org/10.1089/154099903322643938

Centra, J.A. \& Gaubatz, N.B. (2000). Is there gender bias in student evaluations of teaching? Journal of Higher Education, 71(1), 17-26. http://dx.doi.org/10.2307/2649280

Constantinople, A. P., Cornelius, R.R., \& Gray, J. (1988). The chilly climate: Fact or artifact?, Journal of Higher Education, 59, 527- 550. http://dx.doi.org/10.2307/1981702

Crawford, M., \& MacLeod, M. (1990). Gender in the college classroom: An assessment of the 'chilly climate' for women. Sex Roles, 23(3-4), 101-122. http://dx.doi.org/10.1007/BF00289859

Dodd, E. H., Giuliano, T. A., Boutell, J. M., \& Moran, B. E. (2001). Respected or rejected: Perceptions of women who confront sexist remarks. Sex Roles, 45(7/8), 567-577. http://dx.doi.org/10.1023/A:1014866915741 
Dumont, M., Sarlet, M., \& Dardenne, B. (2010). Be too kind to a woman, she'll feel incompetent: Benevolent sexism shifts self-construal and autobiographical memories toward incompetence. Sex Roles, 62(7/8), 545-553. http://dx.doi.org/10.1007/s11199-008-9582-4

Fassinger, P. A. (1995). Professors' and students' perceptions of why students participate in class. Teaching Sociology, 24, 25-33. http://dx.doi.org/10.2307/1318895

Fischer, J.D. (1996). Portia unbound: The effects of a supportive law school environment on women and minority students. UCLA Womens Law Journal, 7(1), 81-130.

Foschi, M. (1996). Double standards in the evaluation of men and women. Social Psychology Quarterly, 59, $237-254$. http://dx.doi.org/10.2307/2787021

Gilligan, C. (1982). In a different voice: psychological theory and women's development. Cambridge, MA: Harvard University Press.

Good, J., \& Rudman, L. (2010). When female applicants meet sexist interviewers: The costs of being a target of benevolent sexism. Sex Roles,62(7/8), 481-493. http://dx.doi.org/10.1007/s11199-009-9685-6

Granfield, R. (1992). Making elite lawyers: Visions of Harvard and beyond. New York, Chapman \& Hall.

Guinier, L., Fine, M., Balin, J., Bartow, A., \& Stachel, D.L. (1994). Becoming gentlemen: Women's experiences at one Ivy League law school. University of Pennsylvania Law Review, 143(1). 1-110. http://dx.doi.org/10.2307/3312516

Hall, R. M., \& Sandler, B.R. (1982). The classroom climate: A chilly one for women? Washington, D.C.: Project on the Status and Education of Women, Association of American Colleges.

Henderson, R.A. (2014). The continuing gender gap in legal education. The Federal Lawyer, Spring, 80-89.

Hostler, S.L., Gressard R,P. (1993). Perceptions of the gender fairness of the medical education environment. Journal of American Medical Women's Association, 48, 51-54.

Hurst, R., \& Beesley, D. (2013). Perceived sexism, self-silencing, and psychological distress in college women. Sex Roles, 68(5/6), 311-320. http://dx.doi.org/10.1007/s11199-012-0253-0

Karp, D. A., \& Yoels, W.C. (1976). The college classroom: Some observations on the meanings of student participation. Sociology and Social Research, 60, 421-439.

Kierstead, D., D’Agostino, P. \& Dill, H. (1988). Sex role stereotyping of college professors: Bias in students' ratings of instructors. Journal of Educational Psychology, 80(3), 342-344. http://dx.doi.org/10.1037/0022-0663.80.3.342

Kitzinger J. (1995). Introducing focus groups. British Medical Journal, 311, 299-302. http://dx.doi.org/10.1136/bmj.311.7000.299

Kling, K.C., Hyde, J.S., Showers, C.J., \& Buswell, N.S. (1999). Gender differences in self-esteem: A meta-analysis. Psychological Bulletin, 125, 470-500. http://dx.doi.org/10.1037/0033-2909.125.4.470

Kogan, L. R., Schoenfeld-Tacher, R., \& Hellyer, P. W. (2010). Student evaluations of teaching: perceptions of faculty based on gender, position, and rank. Teaching In Higher Education, 15(6), 623-636. http://dx.doi.org/10.1080/13562517.2010.491911

Krakauer, L. \& Chen, C. (2003). Gender barriers in the legal profession: Implications for career development of female law students. Journal of Employment Counseling, 45. 65-79. http://dx.doi.org/10.1002/j.2161-1920.2003.tb00857.x

Kramarae, C., \& Treichler, P.A. (1990). Power Relationships in the Classroom. In S. L, Gabriel \& I. Smithson (Eds.), Gender in the classroom: Power and pedagogy, (pp 41-59). Urbana: University of Illinois Press.

Laws, J. (1975). The psychology of tokenism: An analysis. Sex Roles, 1(1), 51-67. http://dx.doi.org/10.1007/BF00287213

Liu, X. (2013). Chinese women in legal education. Indiana Journal of Global Legal Studies, 2, $1311-1357$. http://dx.doi.org/10.2979/indjglolegstu.20.2.1311

Logel, C., Walton, G. M., Spencer, S. J., Iserman, E. C., von Hippel, W., \& Bell, A. E. (2009). Interacting with sexist men triggers social identity threat among female engineers. Journal Of Personality \& Social Psychology, 96(6), 1089-1103. http://dx.doi.org/10.1037/a0015703

McCabe, J.G. (2014). Redefining 'power'. Women Lawyer's Journal, 99, 33-37.

McDonald, T., Toussaint, L., \& Schweiger, J. (2004). The influence of social status on token women leaders' expectations about leading male-dominated groups. Sex Roles, 50(5/6), 401-409. http://dx.doi.org/10.1023/B:SERS.0000018894.96308.52 
Minow, M. (1990). Making all the difference. Ithaca, NY: Cornell University Press.

Morgan, D. (1996). Focus groups. Annual Review of Sociology, 22, 129-152. http://dx.doi.org/10.1146/annurev.soc.22.1.129

Mundy, T. (2013). Engendering 'rural' practice: Women's lived experience of legal practice in regional, rural and remote communities in Queensland. Griffith Law Review, (2), 481-503.http://dx.doi.org/10.1080/10383441.2013.10854784

Murray, J., Byrne, D., \& Koenig-Visagie, L. (2013). Teaching gender studies via open and distance learning in South Africa. Distance Education, 34(3), 339-352.http://dx.doi.org/10.1080/01587919.2013.835775

O'Keefe, T. F., \& Fampel, C.E. (1987). The other face of the classroom: A Student Ethnography. Sociological Spectrum, 2, 141-155. http://dx.doi.org/10.1080/02732173.1987.9981813

Obiora, L. (1996). Neither here nor there: Of the female in American legal education. Law \& Social Inquiry, 21(2). 355-432. http://dx.doi.org/10.1111/j.1747-4469.1996.tb00085.x

Purvis, D. E., Female law students, gendered self-evaluation and the promise of positive psychology. (2012). Michigan State Law Review, 1693. Illinois Public Law Research Paper No. 13-10.

Ramachandran, B. (1998). Re-reading difference: Feminist critiques of the law school classroom and the problem with speaking from experience. Columbia Law Review, 98(7). 1757-1794. http://dx.doi.org/10.2307/1123465

Rhode, D. (1993). Missing questions: Feminist perspectives on legal education. Stanford Law Review, 45(6). 1547-1566. http://dx.doi.org/10.2307/1229112

Sandler, B.R., \& Hall, R.M. (1993). Women faculty at work in the classroom, or, why it still hurts to be a woman in labor. Washington, D.C.: Center for Women Policy Studies.

Schleef, D. (2001). Thinking like a lawyer: Gender differences in the production of professional knowledge. Gender Issues, 19, 69-86. http://dx.doi.org/10.1007/s12147-001-0018-5

Schwab, C. (2003). A shifting gender divide: The impact of gender on education at Columbia Law School in the new millennium. Columbia Journal of Law and Social Problems, Spring/Summer.

Swim, J. K., Mallett, R., \& Stangor, C. (2004). Understanding Subtle Sexism: Detection and Use of Sexist Language. Sex Roles, 51(3/4), 117-128. http://dx.doi.org/10.1023/B:SERS.0000037757.73192.06

Swim, J. K., Eyssell, K. M., Murdoch, E., \& Ferguson, M. J. (2010). Self-silencing to sexism. Journal Of Social Issues, 66(3), 493-507. http://dx.doi.org/10.1111/j.1540-4560.2010.01658.x

Thornton, M. (1996). Dissonance and distrust: Women in the legal profession. Melbourne: Oxford University Press.

U.S. Bureau of Labor Statistics. (2013). Women in the labor force: A databook. Retrieved from http://www.bls.gov/cps/wlf-databook-2012.pdf

Whitworth, J.E., Price, B.A. \& Randall, C.H. (2002). Factors that affect college of business student opinion of teaching and learning, Journal of Education for Business, 77(5), 282-289. http://dx.doi.org/10.1080/08832320209599677

Williams, S. (1993). Feminist epistemology, and the Socratic Method. Stanford Law Review, 45(6). 1571-1576. http://dx.doi.org/10.2307/1229114

Wingate, N. (1984). Sexism in the classroom. Integrated Education, 22, 105- 110.

Wright, R. A., \& Kane, C. C. (1991). Women speak this week: Promoting gender equality and awareness in class discussions. Teaching Sociology, 19(4), 472-476. http://dx.doi.org/10.2307/1317889

Yoder, J.D., Schleicher, T.S., \& McDonald, T.W. (1998). Empowering token women leaders: The importance of organizationally legitimated credibility. Psychology of Women Quarterly, 22, 209-222. http://dx.doi.org/10.1111/j.1471-6402.1998.tb00151.x

\section{(cc) $\mathrm{Br}$}

This work is licensed under a Creative Commons Attribution 3.0 License. 